\title{
Color-Coded Graphic Organizer for Empowering Students' Writing
}

\author{
Mega Mulianing Maharani \\ Universitas Islam Sultan Agung Semarang, Jalan Raya Kaligawe Km.4 Semarang \\ \{megamulianing@unissula.ac.id\}
}

\begin{abstract}
This study investigated color-coded graphic organizer for empowering students' writing. The main aim was to know the students' writing after colorcoded graphic organizer was applied. Following action research methodology, the study discussed the students' writing from two sources: writing and questionnaire. The questionnaire result showed that the biggest problematic sentences was detail sentences, $76 \%$. The writing result after the first intervention showed that the students' writing were vary: their topic was written clearly and the details were correlating the topic; the orientation was written completely, the complicatiton and reorientation were organized well; their sentences were grammatically good except four students; their vocabularies were not very poor; their sentences were written in an appropriate mechanic. However, the writing result after the second intervention showed that there was a student who could not fullfill the criterias of good writing which were about content, organization, grammar, vocabulary and mechanic. In short, the writer could say that color-coded graphic organizer empowered the students' writing. It linked planning stage with drafting and a writing product.
\end{abstract}

Keywords: Color-coded graphic organizer, writing

\section{INTRODUCTION}

Writing is part of main skills that should be mastered by foreign learners. One of the very basic writing introduced to students is paragraph writing. It focuses on sentence making into paragraph making. In paragraph making, they focus on making some types of paragraph.

Narrative paragraph is part of the learning. In providing good narrative story, students should know its structure which consists of orientation, complication, and reorientation. As a second semester students who are still not good in producing paragraph, understanding the essential parts of paragraph: the topic sentence, detail sentences and concluding sentences, is very important for them. Lacking the ability of connecting them is the worst problem faced.

Becoming proficient in paragraph writing is their target to fullfill the study. As the solution for empowering the writing of the second semester students of English education program in the academic year 2018/2019, the writer used color-coded graphic organizer. The writer supposed that it could offer practices of sentence making and paragraph making. One way to understand the students' difficulties is to meet the students' neeed. (McMackin \& Witherell, 2005). Graphic organizer has been applied as academic support with and without disabilities (McDaniel \& Flower, 2015). As the result, various studies have suggested that graphic organizer 
could be applied in solving students' academic problems (Gallavan \& Kottler, 2010; Owolabi \& Adaramati, 2015; Praveen Sam \& Rajan, 2013). However, there were some studies have suggested the use of graphic organizer to solve students' writing (Held \& Ellyn, 2010; Lee \& Tan, 2010; Shaw, Nihalani, Mayrath, \& Robinson, 2012).

By paying attention to the idea that graphic organizers could be used to students without disabilities, therefore, the writer wanted to know the students' writing after the intervention of grahic organizer was applied. Color-coded graphic organizer was applied before they drafted a narrative paragraph. They were treated to understand the ways to apply it.. The writer was eager to know the students' draft after they were treated to create it as the brainstorm of their narrative paragraph.

\subsection{Graphic organizer}

In recent years, educational research has stressed on the role of graphic organizer on writing (Held \& Ellyn, 2010; Ley \& Gannon-cook, 2014). It provides visual illustration of abtract image and opinions which are the subject matter of writing (Ewoldt \& Morgan, 2017) because it is a graphical concepts of texts (Owolabi \& Adaramati, 2015). It is a figure of idea that shows the relation between a concept to another concepts. It illustrates every point of certain topic that the writer wants to discuss. Hence, it links the supported information.

Graphic organizer is like our brain which consists of many connectives. It connects every information stored there. By using it, students can write the content of their writing because they are not only organizing, summarizing, analyzing, but also evaluating. In other words, they stimulate their critical thinking skill. Benefits of graphic organizer as the teaching strategy are many. It has helped students in organizing information in the age of social media (Bartsch, 2013); and describing systematic process for instructional design (Ley \& Gannon-cook, 2014); and assissting students' pre-writing instruction (Held \& Ellyn, 2010).

\subsection{Color-coded graphic organizer}

There are many kinds of graphic organizer. (Hall, McCulley, Wanzek, Kent, \& Davis, 2016) mentioned that there were six types of graphic organizers that could be assissted students' comprehension and even recalled texts contents. (Singleton \& Filce, 2015) in different perspective declared that there were nine types of graphic organizer used in certain demand. The type of graphic organizer used in this study was combined by some colors hence it showed several coded as parts of narrative paragraph. It was in the form of bubble-map. Color-coded gave good step to sustain writing development. Specifically, by adding color to graphic organizers forced students to write another level of organization that were able to create relationship between the keywords and complete sentences in paragraph (Ewoldt \& Morgan, 2017). In other words, it recalls students' memory and attention in developing between unstructured idea and sentences in paragraph.

\subsection{Writing}

Writing is difficult both for native and foreign learners (Faraj, 2015), hence, it needs many practices which can be enganged in the process of writing. If it happened, then it provides chances to students doing many writing activities. As one of academic skills, university students also find that it is difficult (Togatorop, 2015). As a writing lecturer then has a big job to help them in developing ideas into a good writing. They learn its organization as part of the steps in writing process: prewriting, drafting, revising, editing, and publishing (Ewoldt \& Morgan, 2017). In order to know their ability in completing those processes well, their writing should be analyzed by using certian criterias. One of the idea was as proposed by (Terrell \& Brown, 2006) 
who mentioned that there were five criterias in analyzing writing: content, organization, grammar, vocabulary and mechanic.

\section{METHODOLOGY}

\subsection{Design of the study}

This study used classroom action research. One of the reason was because it supported the educational problems solution which improved practice (Carter, 2012). Paying attention to the strengths of action research which gave opportunity to researcher to apply theory, evaluate results, develop new understanding of theory, the researcher decided to use it. In other words, action research addressed a problem and improved practice.

This research applied the idea of action research as suggested by (Norton, 2019) who proposed a simple process for carrying out action research. It consisted of five steps: identifying a problem, thinking about the solution, doing it, evaluating the findings, and modifying future practice, which were called as ITDEM. It was firstly used in analysing students' essay writing. Therefore, the writer was eager to adopt those steps in a same activity, writing.

As the first step, the identifying problem of this study, the writer found the second semester students of English education program problem especially the students who were in paragraph based writing class. As the second step, the thinking about the solution of this study, the writer thought the proper way to solve their paragraph writing problem: distributed questionnaire and designed color-coded graphic organizer as the intervention to help them in sentence making and paragraph making. As the third step, the doing of this study, the writer applied color-coded graphic organizer to the 19 students of second semesterof English education program. As the fourth step, the evaluating of the study, the writer transformed the finding which were based on the questionnaire and students' writing. The finding of the students' writing process helped the writer to evaluate the main problems of sentence and paragraph making. Hence, it was used as the basis for the next step: modifying future practice. As the last step, the modifying future practice of this sudy, the writer identified the results of the previous steps which leaded the writer into the decision whether there would be next cycle or not. In fact, the results told us many interestsing things. Therefore, this part gave illustration to the writer about that decision.

\subsection{The subject of study}

The second semester students of English education program were the subject of this study. There were 19 students participated in this study.

\subsection{Data collection procedure}

There were two procedures of data collection. They were in the forms of questionnaire and writing test data collection. In collecting the data from questionnaire, there were 30 questions distributed to students. It was used for the main information related to the students' problems. Meanwhile, the writer gave three writing tests to the participants: the first writing test was done before the intervention, the second writing test was done after the first intervention, and the last writing test was done after the second intervention.

\subsection{Instruments}

There were two instruments used in this study: close-ended questionnaire and writing tests. The writer distributed the questionnaire before color-coded graphic organizer was implemented. The criterias of questionnaire were about the body of paragraph which consisted 
of topic sentence, detail sentences and concluding sentence; aspect of writing which consisted of content, organization, grammar, vocabulary and mechanic; and the last narrative structure which consisted of orientation, complication and resolution. The writer provided 10 questions for each criterias. While the writing tests were used to know their writing. The writer paid attention to how they wrote sentences into paragraph. The aspects to be focused were about content, organization, grammar, vocabulary and mechanic.

\subsection{Data analysis technique}

There were two techniques of analyzing the data of this study. In analyzing questionnaire, the writer analyze the percentage of each criteria. On the other hand, in analyzing the writing tests, the writer used writing scoring rubric which was adopted from (Terrell \& Brown, 2006) which consisted of five criterias: content, organization, grammar, vocabulary, and mechanic.

\subsection{Procedures of the reserach}

The procedures of the research consisted of several ways. They were assembling the data, coding them, comparing them, building meaning and interpretation, and reporting the outcomes.

\section{FINDINGS AND DISCUSSION}

\subsection{Findings}

The first finding which was from close-ended questionnaire, the writer found that the biggest problem was on the students' difficulty of writing detail sentences; grammar and the difficulty on writing the complication of narrative. The second finding which was from the writing test, the writer found that the students lost their idea for several times. They kept silent without continuing their writing. They thought about the sentences to connect their story. It meant that they lacked vocabularies, forgot the organization of the story, and lacked idea of the story content. In addition, their writing result is explained in the following diagram.

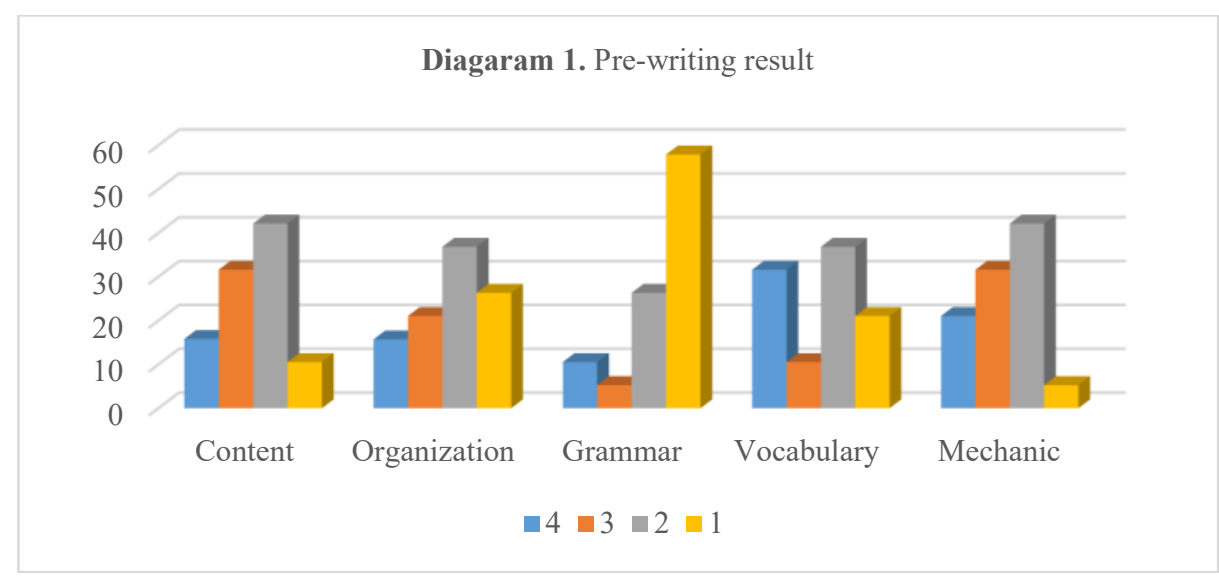

The writer could say that the biggest problem faced by the students was on grammar. The students used frequent grammatical or agreement inaccuracies. The students' writing are as the following examples: 
Table 1. Examples of students' sentences

\begin{tabular}{ll}
\hline Students & Sentences \\
\hline S-1 & Timmy and Tiptoes keep their nuts in the little pedlock. \\
S-3 & When Goody looking for him. \\
S-4 & They passed their life journey which is full of challenge. \\
S-5 & But there nothing. \\
S-6 & Then they was fight. \\
S-7 & She sad and confused. \\
S-8 & He has save their nuts. \\
\hline
\end{tabular}

The writer did the intervention which functioned to help them in connecting between their brainstorm and draft. The graphic organizer was in the form of color-coded bubble map. The students had to use certain color to write each part of narrative structures. They had only to provide the key words of every narrative structures. Their color-coded graphic organizer was their brainstorm which was used to make their narrative draft. It was done in 4 weeks while each week covered two meetings. In the first week, they tried to recall their memory about narrative structure before they decided color they used in their graphic organizers. They also decided the number of paragrahs they would have. In the second week, they decided color and applied it to their graphic organizer. At the same time, they tried to give key words in the it. The key words they wrote in this session was about the topic sentence and detail sentences of each paragraph. In the third week, they were assissted to write concluding sentence. The writer did not forget to give model about conclusion writing. In the fourth week, they read their writing and checked the connection between sentences. Furthermore, they checked their draft whether they needed to revise their sentences or not. In every activities they had during the intervention, the writer assissted them by giving some models. After they finished their writing they had to submit it.

The next step after the intervention was conducting writing test. In this step, the students wrote a narrative of Timmy Tiptoes. The writing result was also evaluated by using similar rubric used in the first writing. The writer paid attention to the result they got in every score of each criteria. The function was to know the students who were in score 4 as the highest score and the ones in score 1 as the lowest score. If the writer still found score 1 in their writing evaluation, it meant that they were not capable of fulfilled the target. The diagram below shows the result or their writing.

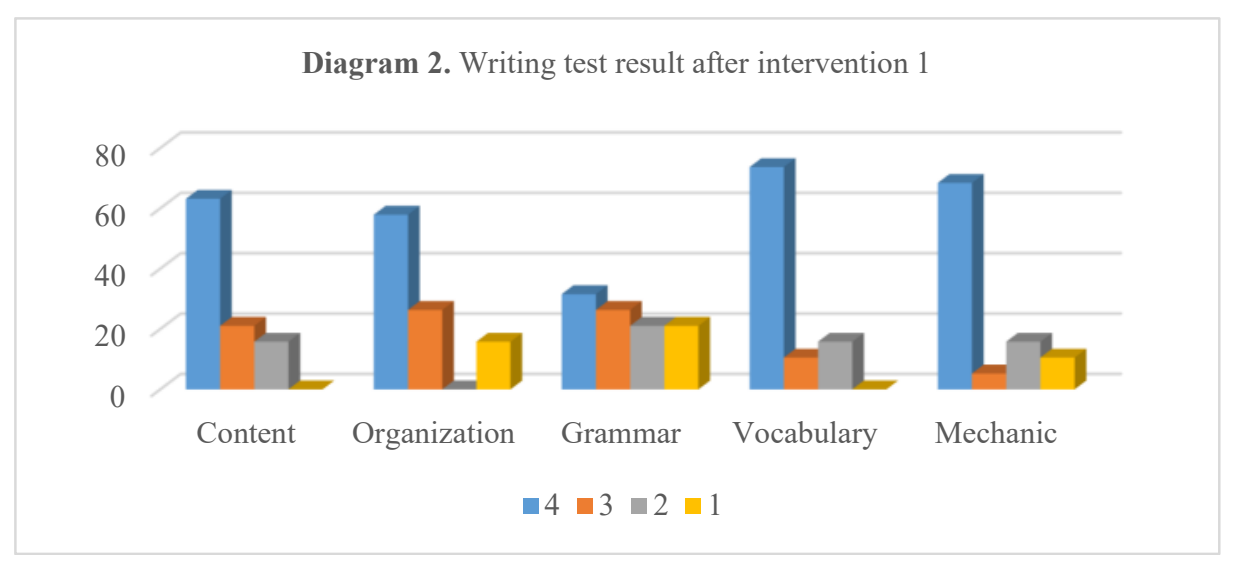


From the result of the students' writing above, the writer found that grammar was the problem. Even it was not as high as the result on the first writing. There were four students who were not capable of writing good sentences. They should have very few grammatical or agreement accuracies. However, they wrote sentences in frequent grammatical or agreement accuracies. The second bad result was organization and the third was mechanic. Meanwhile, the result of content and vocabulary were good. Some of the students' writing are as the following examples:

Table 2. Examples of students' sentences

\begin{tabular}{ll}
\hline Students & Sentences \\
\hline S-9 & Timmy and his wife can meet each other. \\
S-13 & He cannot remember where the nuts. \\
S-18 & Goody will found him. \\
S-19 & He always spend day to work. \\
\hline
\end{tabular}

After the writer analyzed the results above, then the writer decided to have the second intervention by using color-coded graphic organizer. The writer wanted to improve their capablity in writing sentences without producing frequent grammatical or agreement accuracies. At the end of this session, the writer hoped that all students mastered writing of narrative paragraph. Hence, the color-coded graphic organizer could empower them in writing narrative. The results can be read below.

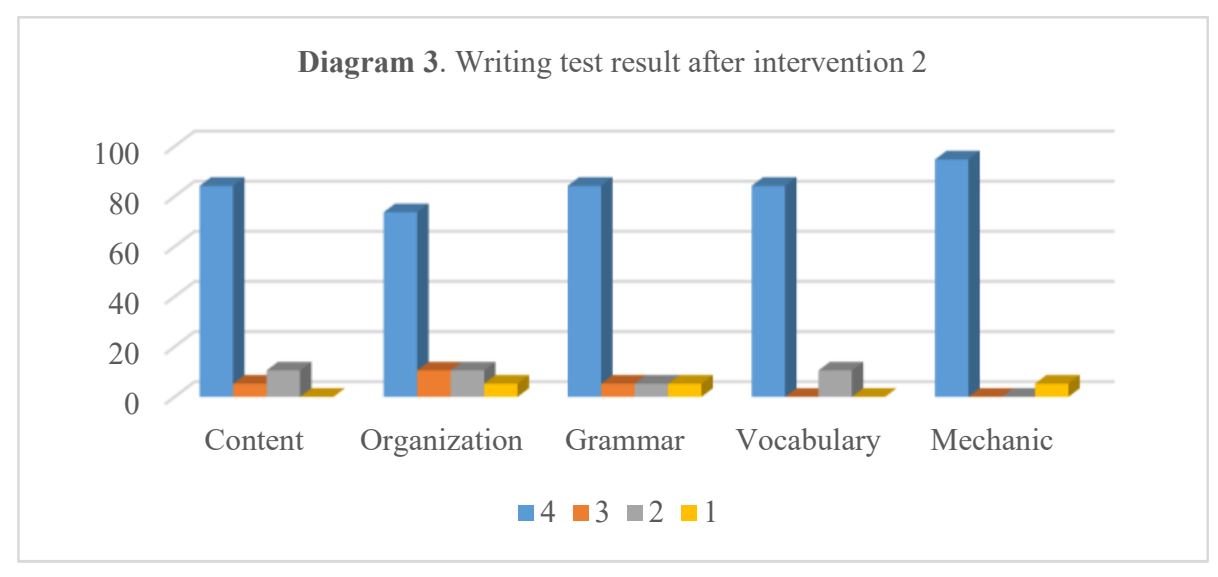

Based on the results above, the writer could say that there were three similar results: organization, grammar, and mechanic. Unfortunately, those results came from a student. Some sentences he made are as the following examples:

Table 3. Examples of students' sentences

\begin{tabular}{ll}
\hline Students & Sentences \\
\hline S-19 (grammar) & $\begin{array}{l}\text { Peter get down and started ran. } \\
\text { S-19 (organization) }\end{array}$ \\
$\begin{array}{l}\text { He sleeped under gate. he get home. Mr. McGregor } \\
\text { catche him. He do not care. } \\
\text { once upon a time there are for little rabbits flopsy } \\
\text { mopsy cottontail and peter }\end{array}$ \\
\hline
\end{tabular}




\subsection{Discussions}

In the writing before the intervention, there were many students could not write topic clearly and even the details were not relating to the topic. In the point of organization, they wrote orientation incompletely, complication and reorientation were arranged with few misuse of connectives. In the point of grammar, they wrote sentences in grammatical or agreement inaccuracies frequently. In the point of vocabulary, they used limited range confusing words and word forms; and they had very poor knowledge or words, word forms, and not understandable. In the point of mechanic, they had occasional errors of spelling, punctuation, and capitalization.

The students' writings after the fist intervention of color-coded graphic organizers were vary too. However, they were better than the previous one. In the point of content, few students could not write topic clearly and even the details were not relating to the topic. In the point of organization, few students wrote identification incompletely and descriptions were arranged with misuse of connectives. In the point of grammar, there were only four students wrote sentences in grammatical or agreement inaccuracies frequently. In the point of vocabulary, few students had very poor knowledge or words, word forms, and not understandable. In the point of mechanic, there were few students' writings were dominated by errors of spelling, punctuation, and capitalization.

The students' writings after the second intervention were better than the first intervention. However, there was one bad writing. It happened to almost all of the criterias. He could not write topic clearly and even the details were not relating to the topic; wrote identification incompletely and descriptions were arranged with misuse of connectives; wrote sentences in grammatical or agreement inaccuracies frequently; had very poor knowledge or words, word forms, and not understandable; and his writing was dominated by errors of spelling, punctuation, and capitalization.

In short, the students' writings were not always similar in every activities. The writing after the first intervention was better than before the intervention. On the other hand, the writing after the second intervention was better than the first one.

\section{CONCLUSION}

Color-coded graphic organizer had been used as the intervention to the students' writing. It was implemented twice during the study. The students wrote two different writings after the implementation. The writer differentiated their writings based on five criterias: content, organization, grammar, vocabulary and mechanic. The students' writings were vary based on the intervention and the criteria. The longer the practice the better the writing. Practices given to students affected their writing ability. Even the writer found there was a student who still needed more practices, the writer could say that color-coded graphic porganizer empowered students' writing.

\section{Acknowledgements}

This work would not have been possible without the financial support of English Education Program of English Languages and Communication Science Faculty of UNISSULA Semarang. I am especially grateful to Huyi Intan Sari, the Chairman of English Education Program, and Hartono, the Chairman of English Languages and Communication Science Faculty of UNISSULA, who have been encouraging of my career goals and who gave protective academic time to reach those goals. 
I am thankful to everyone who gave chance, time, energy, and even permission to work during this study. The second semester students of paragraph based writing class in the academic year of 2018/2019 who were very cooperative in conducting this study. I would like especially to thank Amalia Nur Fauziah, leader of Education Class, who organized everything well.

\section{References}

[1] Bartsch, R. A. (2013). Designing SoTL studies--Part II: Practicality. New Directions for Teaching and Learning, (136), 35-48. https://doi.org/10.1002/tl

[2] Carter, N. (2012). Action research: Improving graduate-level writing. Educational Action Research, 20(3), 407-421. https://doi.org/10.1080/09650792.2012.697403

[3] Ewoldt, K. B., \& Morgan, J. J. (2017). Color-Coded Graphic Organizers for Teaching Writing to Students With Learning Disabilities. TEACHING Exceptional Children, 49(3), 175-184. https://doi.org/10.1177/0040059916681769

[4] Faraj, A. K. A. (2015). Scaffolding EFL Students' Writing through the Writing Process Approach. Journal of Education and Practice, 6(13), 131-142. https://doi.org/10.1109/ETCS.2009.134

[5] Gallavan, N. P., \& Kottler, E. (2010). Visualizing the Life and Legacy of Henry VIII: Guiding Students with Eight Types of Graphic Organizers. The Social Studies, 101(3), 93102. https://doi.org/10.1080/00377991003711699

[6] Hall, C., McCulley, L., Wanzek, J., Kent, S. C., \& Davis, A. (2016). A New Look at Mnemonics and Graphic Organizers in the Secondary Social Studies Classroom. TEACHING Exceptional Children, 46(1), 47-55. https://doi.org/10.1177/004005991304600106

[7] Held, S., \& Ellyn, G. (2010). Organizers for a more effective approach to prewriting instruction. Illinois Reading Council Journal, 38(3), 20-29.

[8] Lee, C. C., \& Tan, S. C. (2010). Scaffolding writing using feedback in students' graphic organizers - novice writers' relevance of ideas and cognitive loads. Educational Media International, 47(2), 135-152. https://doi.org/10.1080/09523987.2010.492678

[9] Ley, K., \& Gannon-cook, R. (2014). Vital signs for instructional design. The Quarter, $15(2), 21-34$.

[10] McDaniel, S. C., \& Flower, A. (2015). Use of a Behavioral Graphic Organizer to Reduce Disruptive Behavior. Education and Treatment of Children, 38(4), 505-522. https://doi.org/10.1353/etc.2015.0016

[11] McMackin, M. C., \& Witherell, N. L. (2005). Different Routes to the Same Destination: Drawing Conclusions With Tiered Graphic Organizers. The Reading Teacher, 59(3), 242 252. https://doi.org/10.1598/rt.59.3.4

[12] Norton, L. (2019). Action Research in Teaching and Learning. Action Research in Teaching and Learning. https://doi.org/10.4324/9781315147581

[13] Owolabi, J., \& Adaramati, T. F. (2015). Effects of graphic organiser on students achievement in algebraic word problems. Journal of Education and Practice, 6(5), 39-45.

[14] Praveen Sam, D., \& Rajan, P. (2013). Using graphic organizers to improve reading comprehension skills for the middle school ESL students. English Language Teaching, 6(2), 155-170. https://doi.org/10.5539/elt.v6n2p155

[15] Shaw, S., Nihalani, P., Mayrath, M., \& Robinson, D. H. (2012). Graphic organizers or graphic overviews? Presentation order effects with computer-based text. Educational Technology Research and Development, 60(5), 807-820. https://doi.org/10.1007/s11423- 
012-9257-2

[16] Singleton, S. M., \& Filce, H. G. (2015). Graphic Organizers for Secondary Students With Learning Disabilities. TEACHING Exceptional Children, 48(2), 110-117. https://doi.org/10.1177/0040059915605799

[17] Terrell, T. D., \& Brown, H. D. (2006). Principles of Language Learning and Teaching. Language (Vol. 57). https://doi.org/10.2307/414380

[18] Togatorop, E. (2015). Teaching writing with a web based collaborative learning. International Journal of Economics and Financial Issues, 5(Cl), 247-256. Retrieved from https://www.scopus.com/inward/record.uri?eid=2-s2.0-

84979844508 \&partnerID $=40 \& \mathrm{md} 5=\mathrm{f} 9 \mathrm{~b} 7 \mathrm{f} 1 \mathrm{dc} 176 \mathrm{e} 7856 \mathrm{ce} 8 \mathrm{a} 24 \mathrm{db} 2 \mathrm{a} 78 \mathrm{c} 4 \mathrm{~b} 9$ 